DOI: $10.31933 / \mathrm{DIJMS}$

Received: $11^{\text {st }}$ August 2020, Revised: $15^{\text {th }}$ September 2020, Publish: $5^{\text {th }}$ November 2020

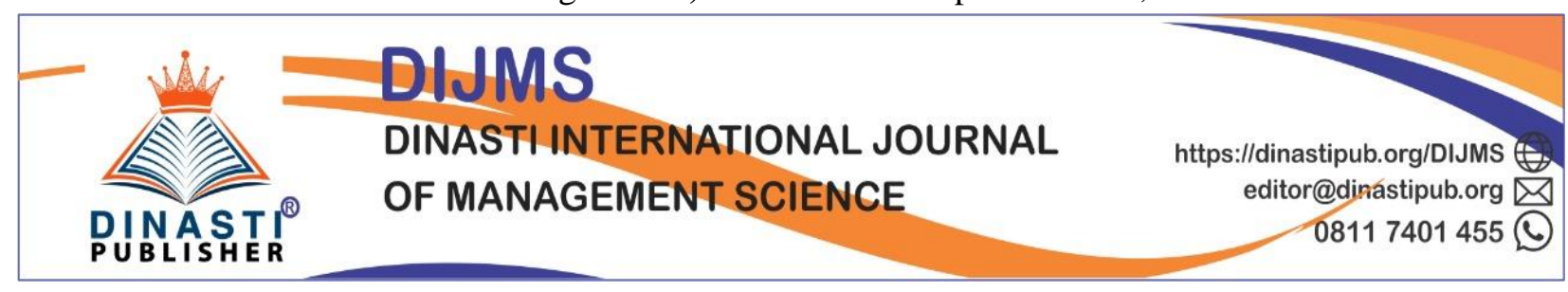

\title{
IMPLEMENTATION OF A WHISTLEBLOWING SYSTEM ON FRAUD DETECTION AT PT JR (CASE STUDY ONE OF STATE OWNED ENTERPRISES IN INDONESIA)
}

\author{
Budi Rahman \\ Mercu Buana University, Jakarta, Indonesia, budirahman210@yahoo.com
}

\section{Corresponding Author: Budi Rahman}

\begin{abstract}
Reporting system or whistleblowing system is a means for whistleblower to report fraud or violations committed by internal organizations. This system aims to uncover fraud that can harm the organization and prevent even more fraud. This research is a case study at PT JR with the aim of this research is to find out the implementation of the whistleblowing system on fraud deetection at PT JR. The method used in this study is a combination method or mix methods. Data collection techniques using triangulation methods, namely quantitative data collection through questionnaires while qualitative through interviews and documents. Analyze data with a descriptive approach to get a real picture of the whistleblowing system at PT JR. The study population is an internal auditor at PT JR with the results of the study showing that the Whistleblowing System has a positive and significant effect on Fraud Detection.
\end{abstract}

Keywords: Whistleblowing System, Fraud Detection

\section{INTRODUCTION}

The increase in white-collar crime in various parts of the world has encouraged various countries and business associations to take various preventive measures and increasingly increase the demands for the implementation of good governance in both the private and public sectors. According to the Whistleblowing System (WBS). Wrongdoing Reporting System Guideline, The National Committee on Governance Policy [2], which is one form of implementing good corporate governance (GCG), is the Whistleblowing System. In addition to better corporate governance, the Whistleblowing System arises because of the increasing number of cases of fraud, financial irregularities, and is part of an internal control. To reduce the case of fraud, a Whistleblowing System was formed which is expected to be an effective tool in minimizing fraud in companies and governments.

Fraud is an dishonest act that raises the potential for real harm to the company or company employees or others, but is not limited to corruption, money theft, theft of goods, fraud, forgery. Also included in this act is the falsification, concealment or destruction of documents or reports, or using fake documents for business purposes, or leaking company information to external parties. Fraud like this is usually done by employees in the company or organization

Violation reporting system or commonly called the Whistleblowing System is a container for a whistleblower reporter to complain about fraud or violations committed by internal parties of the organization. This system aims to uncover fraud that can harm the organization and prevent 
even more fraud.

The role of the whistleblower as a form of oversight of organizational performance. This is because whistleblowers can be played by anyone who knows fraud in an organization. However, many people are afraid to complain about fraud, because there are not a few risks that must be faced, even difficult to avoid and the solution is they prefer to remain silent. Starting from the threat reported to himself and his family and the threat of dismissal.

According to the Corruption Perception Index issued by Transparency International in 2017 [18], from 180 countries rated in the 2017 index that Indonesia is in position 96 with a score of 37. While for the Asia Pacific region, Indonesia is in position 17 out of 31 countries that were assessed. Even so, the score should be appreciated as a result of working together with the government, the community, and businesses to prevent and eradicate corruption.

According to Arens [5], there are three elements to prevent fraud, one of which is by applying a culture of honesty and high ethics. The most effective way to prevent and deter fraud is to implement anti-fraud programs and controls, which are based on the company's core values. These values help create an honest and ethical culture that forms the basis of employee work responsibilities and encourages employees to behave ethically.

An honest and high ethical culture creates a positive work environment. A positive work environment can be realized by implementing a whistleblowing program for employees to report violations of the code of conduct. Public awareness about whistleblowing is also very effective in exposing corruption and fraud.

The results of a survey conducted by the Association of Certified Fraud Examiners, ACFE Indonesia in 2016 [19], stated that Internal Auditors have not played an optimal role in fraud prevention in Indonesia, where the ACFE survey data shows that the internal audit department is only $8 \%$ in helping fraud prevention. While the one that plays a role in fraud prevention is the whistleblowing hotline mechanism, which is $20.6 \%$.

With a whistleblowing system in a company, it is very important to oversee internal performance. Supervision is not enough to only be done by superiors and internal audits, but fellow employees also indirectly supervise each other. In addition to monitoring performance, employees can also report violations committed by fellow employees and their evidence through a whistleblowing system that is directly connected to the Internal Audit section of the company responsible for the organization's internal control system. Furthermore, Internal Audit will receive, examine, and follow up on these complaints, and will keep the identity of the reporter confidential and provide security and protection as well as reward for his courage in reporting violations.

Considering that the whistleblowing system is quite effective in detecting fraud, currently almost most government agencies have a complaint handling system to reduce the phenomenon of corruption in public institutions. An effective, transparent and responsible whistleblowing system will encourage and increase employee participation to report suspected fraud. However, until now there has not been much seen how the role of reporting and protection systems for whistleblowers can encourage the emergence of whistleblowers in the government sector.

This research is a case study at PT JR, one of state owned enterprise in Indonesia.

\section{LITERATURE REVIEW \\ Whistleblowing System and Whistleblowers}

The National Committee on Governance Policy - KNKG [2] defines whistleblowing (reporting violations) as "Disclosure of violations or disclosure of acts that are against the law, unethical or immoral acts or other actions that can harm the organization or stakeholders, committed by employees or leaders of the organization to head of the organization or other institutions can take action on violations. This disclosure is generally carried out in secret (confidential).

Whistleblowers are reporters of violations, they can be employees of the organization itself (internal parties), but there are no closed reporters from customers, suppliers, the public (external parties). The requirement for a whistleblower in this concept is to have accurate information, evidence or indications regarding the reported violations and good faith and is not a personal complaint of a particular company policy or is based on bad will or slander so that the information revealed, can be traced or acted upon. Whistleblowers are very helpful for companies and stakeholders in combating fraud [1]. 


\section{Theory of Planned Behavior}

This theory states that the central factor of individual behavior is that the behavior is influenced by individual intentions towards that particular behavior. The intention to behave is influenced by attitude variables, subjective norms, and perceived behavioral control [10]. Behavior is a function of information or beliefs / beliefs that stand out about the behavior. People can have a variety of beliefs about a behavior, but when faced with a particular event, only a few of these beliefs arise to influence behavior. It is this little belief that stands out in influencing individual behavior.

\section{Prosocial Organizational Behavior Theory}

One of the theories supporting whistleblowing is Prosocial Organizatinal Behavior Theory. Brief and Motowidlo (1986) [12] define prosocial organizational behavior as behavior / actions taken by members of an organization towards individuals, groups, or organizations aimed at improving the welfare of individuals, groups, or organizations. This theory explains that positive behavior is carried out not only in the public interest, but also in the interests of the individual himself.

\section{Hypothesis}

Based on the description above, the hypothesis for this study is as follows: The effect of the whistleblowing system on fraud detection at PT JR.

\section{RESEARCH METHODS}

\section{Data Collection Methods and Tecniques}

This research method uses a combination of research methods or mix methods. The combination method is a research approach that involves collecting quantitative and qualitative data [6]. Data collection techniques using triangulation methods, namely quantitative data collection through questionnaires while qualitative through interviews and documents.

This research case study in PT JR and population determination using purposive sampling technique where the determination of the sample technique with certain considerations, namely the Internal Auditor PT. JR with the reason that is directly related to the management of the duties and responsibilities of implementing the Whistleblowing System in the company.

The sample questionnaire was 30 Internal Auditors of PT. JR using the Likert scale one to five. And supported by interviews conducted by three participants, namely Head of Internal Auditor, Head of the Investment Division and Corporate Secretary.

\section{Research Model}

The data of this study will be analyzed using Partial Least Squares (PLS) with SmartPLS 3 software and qualitative analysis based on interviews results. The model and construction are depicted in Figure 1.

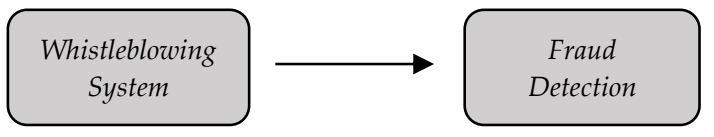

Fig 1. Research Model

\section{Variable Operationalization \\ Latent Variable}

There are two latent variable in this study, namely whistleblowing system and detection fraud. The questionnaire uses question with 5 Likert scales from disagreeing to agreeing. And supported by interviews conducted by 3 participants, namely the Division Head in the company (Head of Internal Auditor, Head of the Investment Division and Corporate Secretary).

\section{Whistleblowing System}


The dimension of whistleblowing system are behavior and seriousness wrongdoing level.

\section{Fraud Detection}

The dimension of fraud detection are internal control system.

\section{Observed Variable}

The variables in this study consist of 13 questions. The latent variable, behavior attitudes (SP) consist of 8 observed variable with symbol on the path diagram, namely (SP.1), (SP.2), (SP.3), (SP.4), (SP.5), (SP.6), (SP.7), (SP.8). The latent varible, seriousness of wrongdoing level consist of 2 observed variable, namely (TKK.1), (TKK.2), (TKK.3). The latent variable, internal control system consist of 3 variable, namely (PI.1), (PI.2), (PI.3). The structural model of the research can be seen in Fig. 2

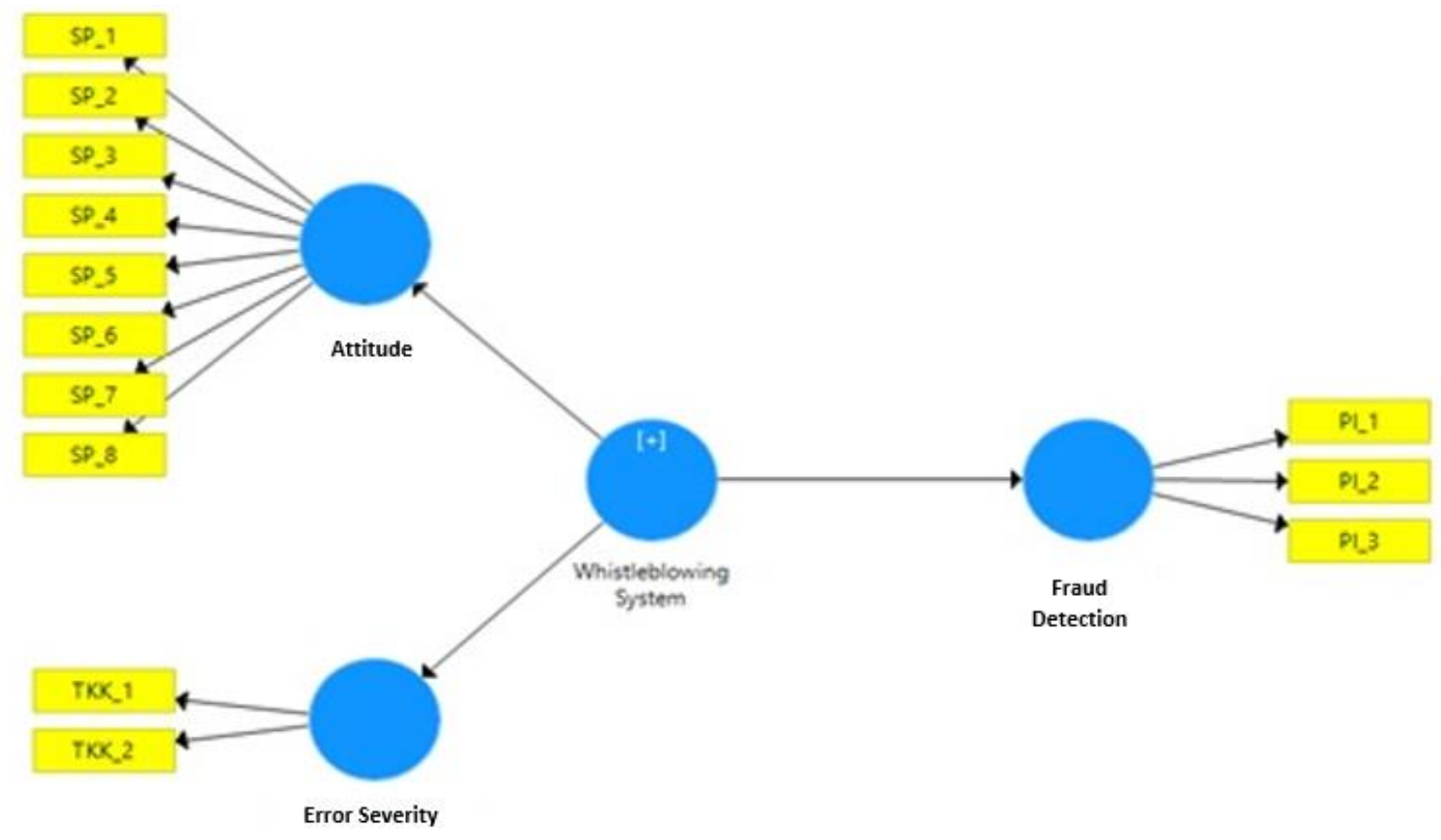

Fig.2 Structure Model

\section{Data Analysis Methods}

Data derived from questionnaires that have been returned by the respondent and fulfil the requirements to be processed, then processed with Partial Least Squares (PLS) with SmartPLS Software 3.

\section{FINDINGS AND DISCUSSION \\ Descriptive of Research}

The respondent of this study is 30 Internal Auditors. The demographics of the respondents are explained in criteria such as gender, job position, work experience, age and education scale. Based on gender dominated by male at $80 \%$. Based on job position dominated by young auditors level I at 26,7\%. Based on work experience predominately with work experience of 4 to 7 years at $53,3 \%$. Based on level age dominated by 45 years old at $16,7 \%$. And based on educational background dominated by bachelor's degree at $66,7 \%$. 
Table. 1 Demographic respondents

\begin{tabular}{|c|c|c|c|c|c|c|c|c|c|}
\hline \multicolumn{2}{|c|}{$\begin{array}{c}\text { Gender } \\
(\%)\end{array}$} & \multicolumn{2}{|c|}{$\begin{array}{c}\text { Job Position } \\
(\%)\end{array}$} & \multicolumn{2}{|c|}{\begin{tabular}{|c|} 
Work \\
Experience \\
$(\%)$ \\
\end{tabular}} & \multicolumn{2}{|c|}{$\begin{array}{l}\text { Age } \\
(\%)\end{array}$} & \multicolumn{2}{|c|}{$\begin{array}{l}\text { Educational } \\
\text { Background }\end{array}$} \\
\hline Male & 80 & \begin{tabular}{|c|} 
Ajun \\
Auditor
\end{tabular} & 10 & $\begin{array}{l}\geq 10 \\
\text { years }\end{array}$ & 10 & $\begin{array}{c}34 \\
\text { years } \\
\text { old }\end{array}$ & 6,7 & Bachelor & 66,7 \\
\hline Female & 20 & $\begin{array}{c}\text { Auditor } \\
\text { Madya } \\
\text { I }\end{array}$ & 13,3 & $\begin{array}{l}1 \text { to } 3 \\
\text { years }\end{array}$ & 33 & $\begin{array}{c}42 \\
\text { years } \\
\text { old }\end{array}$ & 6,7 & $\begin{array}{c}\text { Post } \\
\text { Graduate }\end{array}$ & 33,3 \\
\hline & & $\begin{array}{c}\text { Auditor } \\
\text { Madya } \\
\text { II }\end{array}$ & 26,7 & $\begin{array}{l}4 \text { to } 7 \\
\text { years }\end{array}$ & 53 & $\begin{array}{c}44 \\
\text { years } \\
\text { old }\end{array}$ & 6,7 & & \\
\hline & & $\begin{array}{l}\text { Auditor } \\
\text { Muda }\end{array}$ & 26,7 & $\begin{array}{c}8 \text { to } 10 \\
\text { years }\end{array}$ & 3,3 & $\begin{array}{c}50 \\
\text { years } \\
\text { old }\end{array}$ & 13,3 & & \\
\hline
\end{tabular}

\section{Examination Stages and Results}

The number of respondents who qualified for the analysis was 30 people. The examination is carried out following the stages in PLS, namely by evaluating the outer model and inner model. The stability of the estimation wa evaluted using $\mathrm{T}$ test obtained with the bootstrapping procedure.

\section{Evaluation of Outer Model \\ Convergent Validity}

The validity criteria of this study are seen from loading factors. For the initial research phase of development, the scale of measurement of loading values from 0.5 to 0.6 is considered sufficient [11]. Based on the indicator of convergent validity test, that all indicator loading factor value are above 0.5 . The results of convergent validity test can be seen in Table 2 .

Table. 2 Convergent Validity Results Test

\begin{tabular}{|c|c|c|c|c|}
\hline Dimensi & Indicator & Loading Factor & Cut Off & Information \\
\hline \multirow{2}{*}{$\begin{array}{c}\text { Fraud } \\
\text { Detection }\end{array}$} & PI_1 & 0.823 & 0.5 & Valid \\
\cline { 2 - 5 } & PI_2 & 0.902 & 0.5 & Valid \\
\cline { 2 - 5 } & PI_3 & 0.921 & 0.5 & Valid \\
\hline \multirow{2}{*}{$\begin{array}{c}\text { Behavior } \\
\text { Attitudes }\end{array}$} & SP_1 & 0.744 & 0.5 & Valid \\
\cline { 2 - 5 } & SP_2 & 0.763 & 0.5 & Valid \\
\cline { 2 - 5 } & SP_3 & 0.777 & 0.5 & Valid \\
\cline { 2 - 5 } & SP_4 & 0.787 & 0.5 & Valid \\
\cline { 2 - 5 } & SP_5 & 0.717 & 0.5 & Valid \\
\cline { 2 - 5 } & SP_6 & 0.576 & 0.5 & Valid \\
\hline
\end{tabular}




\begin{tabular}{|c|c|c|c|c|}
\hline & SP_7 & 0.684 & 0.5 & Valid \\
\cline { 2 - 5 } & SP_8 & 0.686 & 0.5 & Valid \\
\hline $\begin{array}{c}\text { Seriousness } \\
\begin{array}{c}\text { Wrongdoing } \\
\text { Level }\end{array}\end{array}$ & TKK_1 & 0.911 & 0.5 & Valid \\
\cline { 2 - 5 } & TKK_2 & 0.951 & 0.5 & Valid \\
\hline
\end{tabular}

Sources : Output SmartPLS 3

\section{Discriminant Validity and Composite Reliability}

The methods for assessing discriminant validity is based on the average variance extracted (AVE) value of each construct. Recommended AVE values must be gretaher than 0.5 [21]. The reliability indicators that measure a construct can be evaluated if the cronbachs alpha value is greater than 0.6 and the composite reliability values is greater than 0.7 [21]. The results of discriminant validity test and composite reliability tes can be seen in table 3 and 4 .

Table.3 Discriminant Validity Result Test

\begin{tabular}{|l|c|c|c|}
\hline \multicolumn{1}{|c|}{ Indicator } & Detection Fraud & Behavior & $\begin{array}{c}\text { Seriousness } \\
\text { Wrongdoing Level }\end{array}$ \\
\hline PI_1 & $\mathbf{0 . 8 2 3}$ & 0.316 & 0.372 \\
\hline PI_2 & $\mathbf{0 . 9 0 2}$ & 0.312 & 0.532 \\
\hline PI_3 & $\mathbf{0 . 9 2 1}$ & 0.528 & 0.480 \\
\hline SP_1 & 0.730 & $\mathbf{0 . 7 4 4}$ & 0.598 \\
\hline SP_2 & 0.169 & $\mathbf{0 . 7 6 3}$ & 0.126 \\
\hline SP_3 & 0.327 & $\mathbf{0 . 7 7 7}$ & 0.212 \\
\hline SP_4 & 0.381 & $\mathbf{0 . 7 8 7}$ & 0.445 \\
\hline SP_5 & 0.022 & $\mathbf{0 . 7 1 7}$ & 0.173 \\
\hline SP_6 & 0.368 & $\mathbf{0 . 5 7 6}$ & 0.376 \\
\hline SP_7 & 0.170 & $\mathbf{0 . 6 8 4}$ & 0.248 \\
\hline SP_8 & 0.309 & $\mathbf{0 . 6 8 6}$ & 0.530 \\
\hline TKK_1 & 0.506 & 0.322 & $\mathbf{0 . 9 1 1}$ \\
\hline TKK_2 & 0.478 & 0.557 & $\mathbf{0 . 9 5 1}$ \\
\hline SOurces: & & & \\
\hline
\end{tabular}

Sources : Output SmartPLS 3

Table.4 Composite Reliability Result Test

\begin{tabular}{|c|c|c|c|}
\hline $\begin{array}{c}\text { Dimension } \\
\text { /Variable }\end{array}$ & $\begin{array}{c}\text { Cronbach's } \\
\text { Alpha }\end{array}$ & $\begin{array}{c}\text { Composite } \\
\text { Reliability }\end{array}$ & Information \\
\hline $\begin{array}{c}\text { Fraud } \\
\text { Detection }\end{array}$ & 0.860 & 0.914 & Reliable \\
\hline Behavior & 0.865 & 0.895 & Reliable \\
\hline $\begin{array}{c}\text { Seriousness } \\
\text { Wrongdoin } \\
\text { g Level }\end{array}$ & 0.849 & 0.928 & Reliable \\
\hline
\end{tabular}


Sources : Output SmartPLS 3

\section{Evaluation of Inner Model \\ R-Square Dependen Construct}

The coefficient of determination $\left(\mathrm{R}^{2}\right)$ is used to determine the ability of endogenous variables to explain the diversity of exogenous variables or in other words to find out the magnitude of the contribution of exogenous variables to endogenous variables.

Table 5. R-Square Result Test

\begin{tabular}{|c|c|}
\hline Variable & R Square \\
\hline Fraud Detection & 0,306 \\
\hline
\end{tabular}

The table above shows that the R-square value of the Fraud Detection variable is 0.306 or $30.6 \%$ that the diversity of the Fraud Detection variable can be explained by the Whistleblowing System variable of $30.6 \%$. The contribution of the Whistleblowing System variable to Fraud Detection is $30.6 \%$, while the remaining $69.4 \%$ is contributed by other variables not discussed in this study.

\section{Q-Square Predictive}

Q-Square value can be used to measure how well the observed values generated by the model and estimation parameters. Q-Square value greater than 0 (zero) indicates that the model has a predictive relevance value, while Q-Square value less than 0 (zero) indicates that the model lacks predictive relevance value. The result of Q-Square value of 0.193, it means the Q-square value gretater than zero indicating that the model has a predicitive relevance value.

\section{Hyphotesis Examination}

To test the hypothesis, the partial T-statistic value of each direct influence is used. Path diagram for hypothesis testing can be seen in Fig.3.

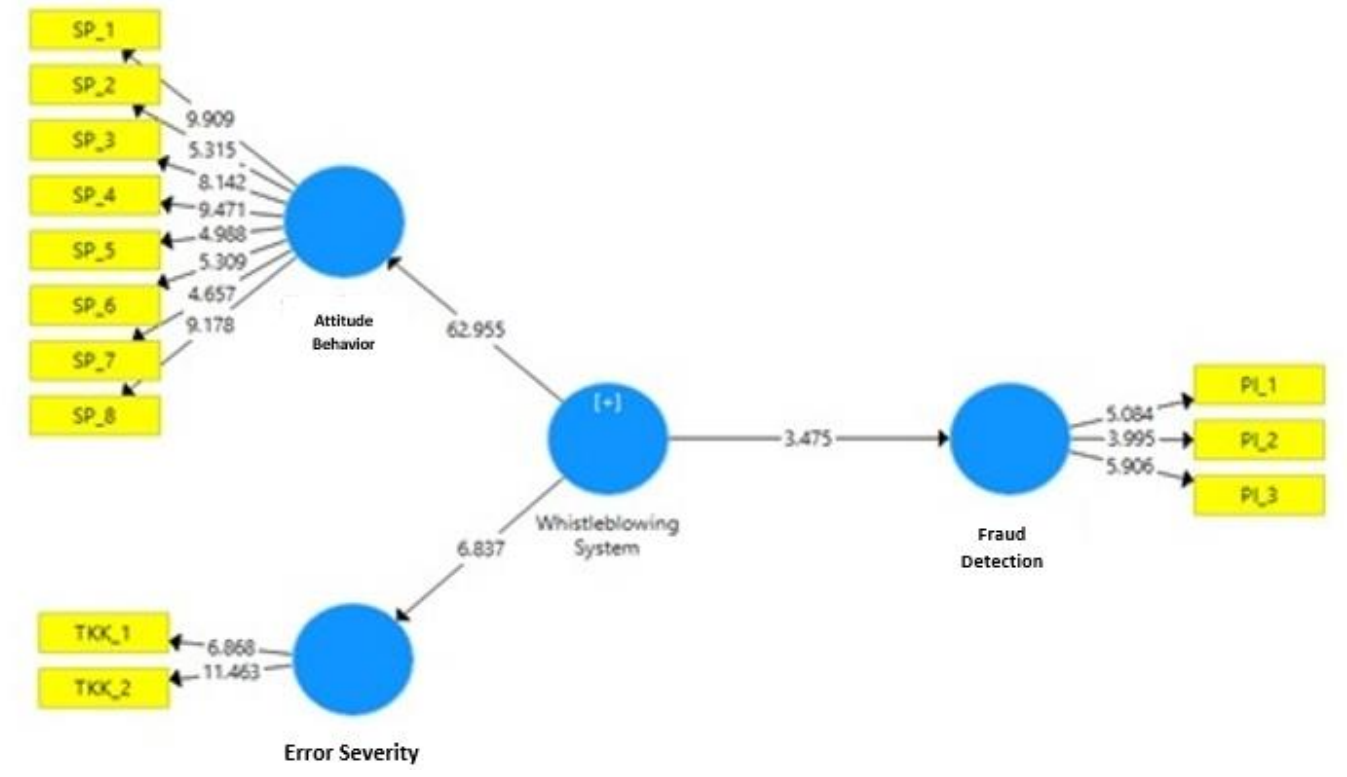

Fig. 3. Path Diagram

The test correlation between variables (hypothesis testing) used T-statistic values from SmartPLS output compared to T-table values, can be seen in table 6 
Table.6 Hyphotesis Examination Results test

\begin{tabular}{|c|c|c|c|c|}
\hline Effect & $\begin{array}{c}\text { Original } \\
\text { Sample (O) }\end{array}$ & $\begin{array}{c}\text { T Statistics } \\
(\mid \mathbf{O} / \text { STDEV })\end{array}$ & PValues & Information \\
\hline $\begin{array}{c}\text { Whistleblowi } \\
\text { ng System } \rightarrow \\
\begin{array}{c}\text { Fraud } \\
\text { Detection }\end{array}\end{array}$ & 0.553 & 3.475 & 0.001 & Significant \\
\hline
\end{tabular}

Sources : Output SmartPLS 3

The test results listed in the table above can be seen that the T-statistic value is 3.475 with a pvalue of 0.001 . The test results show that the T-statistic value $>1.96$ and $p$-value $<0.05$. This means that it can be concluded that there is a significant influence on the Whistleblowing System on Fraud Detection. Thus the hypothesis is fulfilled. The resulting coefficient of 0.553 (positive), thus can be interpreted, if the higher the Whistleblowing System, it tends to increase the Fraud Detection.

\section{Analysis of Examination Result Perception of Respondent on Attitude Behavior}

The result of questionnaires analysis explained as following :

1. Indicators of upholding ethics has a high average value 4.33 which indicate that respondents have a high desire to be a whistle-blower because of fairness and professional ethics. This result is supported by the results of the interview that the respondent reported a violation or fraud professionally and according to the procedure because there was an appeal and socialization from his audit colleagues.

2. Indicators support morality has a high average value is 4.13 which indicates that respondents have a high desire become a whistle-blower because it supports morality. These results are supported by the results obtained from the interviews that the respondents may still report a violation even though his co-workers when they are too vulgar and the attitude of the offender is not good.

3. Reward indicator has a very low average value of 1.20 which indicates that respondents tend not to be willing to be a whistle-blower to receive prize money or promotions. Based on the interview, respondents will be given rewards by the company when reporting violations at PT JR through the whistleblowing system. This shows that the intention of the respondents to be a whistle-blower is not to receive prize money or promotions, although the company will still give rewards if the respondent reports violations to PT JR through the whistleblowing system.

4. Whistleblowing Policy Indicator has a high average value of 4.27 which indicates that respondents tend to have a high desire to be a whistleblower to comply with whistle-blowing policies or laws. This is supported by the results obtained from the interviews that the respondents report a violation or fraud appropriate policies, procedures, and reporting systems in PT JR.

5. Indicators of Encouragement friends have a very low average value of 1.33 which shows that respondents tend not to be willing to be a whistle-blower because of the encouragement of their friends. This result is different from the results of the interview that the respondents felt reluctant in reporting coworkers' violations and felt the violations were not significant.

6. Whistleblower Protection Indicator has a sufficient average value of 3.47 which indicates that respondents tend to be quite willing to be a whistle-blower because of job protection as determined by the law and organizational policy. This result is supported from interviews that Respondents will be given identity protection and protection from harassment or threats from any party both individuals and organizations against reports submitted by reporters of violations.

7. The revenge organization indicator has a very low average value of 1.40 which indicates that 
respondents tend not to be willing to be whistle-blowers because my organization might take revenge on themselves. This result is supported by the results of the interview. That the respondent will report violations or fraud because it can harm the company.

8. Indicators Individual revenge has a low average value of 1.57 which indicates that respondents tend not to be willing to be whistle-blowers because people who engage in illegal, immoral practices from their organizations might take revenge on themselves. This result is supported by the results of interviews that employees report fraud or violations through the violation reporting system at PT JR because they feel responsible for the company and can eliminate company assets.

\section{Perception of Respondent on Seriousness Wrongdoing Level}

The result of questionnaires analysis explained as following :

1. The Amount loss indicator has a sufficient average value of 2.87 which shows that respondents intention to conduct a whistle-blower will be normal, even though the amount of money from illegal, immoral or illegitimate practices in the organization is larger. This result is supported by the results of interviews that respondents will report violations or fraud because it can harm the company.

2. Impact indicators of fraud have pretty average value is 3.47 which indicates that the intention of respondents to the whistle-blower would be greater, if the impact of the practice is illegal, immoral or illegitimate in the organization threatening to society. This result is supported from interviews that employees report fraud or violations through WBS at PT JR because they feel responsible for the company and can eliminate company assets.

\section{Perception of Respondent on Internal Control System}

The result of questionnaires analysis explained as following :

1. The internal control system indicator has a high average value of 4.30 which indicates that respondents are willing to be a whistle-blower if the organization has an effective internal control system to prevent employees from making mistakes or fraud. This result is supported by interviews that the internal control system at PT JR already has SOPs, rules and policies with the board of commissioners and directors to prevent fraud.

2. The Legal Indicator of the organization has a high average value of 4.10 which indicates that the respondent is willing to be a whistle-blower if the organization has a strong legal system, where illegal, immoral or illegal practices can be prosecuted by the authorities. This result is supported by the results of interviews that the fraud report at PT JR will be investigated and followed up by the Internal Auditor after it is proven that the information is correct and the report validation.

\section{CONCLUSION AND SUGGESTION}

According to the results of data analysis where suggestions for improvements related to the implementation of the whistleblowing system on fraud detection at PT JR are as follows:

1. Internal control systems in PT JR less than the maximum because there are financial transactions are carried out manually.

2. The legal system in PT JR organization is still weak due to the protection of whistle-blowers is not fully guaranteed confidentiality by the company.

3. The application of the code of conduct in PT JR is still weak because there are some midlevel officials do not yet have the integrity and adheres well to supervise.

Suggestion for Research :

\section{Operational Solution}

a. Turning financial transactions carried out manually into automation and increasing continuous auditing.

b. The responsibility and management of the Whistleblowing System is carried out by an 
independent third party so that whistle blowers are guaranteed their confidentiality.

c. Ethics training and instill moral values to employees on a regular basis in order to establish the individual who adhere to the code of ethics of the organization.

\section{Knowledge Development Suggestion}

The method used in this study could be developed by other research methods deeper and using other theories related to the implementation of whistleblowing as well as adding other variables related to whistleblowing as Continuous Usage Effectiveness Auditing.

\section{Regulation Suggestion}

a. Necessary to formulate an official policy governing whistleblowing, including the concept and choice of models whistleblowing system, an acceptable reporting criteria, accountability, follow up, the security and confidentiality of data and the reporting of violations and legal protection.

b. Need to do a reconstruction of the existing regulations to give greater certainty whistleblower protection set out in specific legislation.

c. Need to formulate a statement of support model in the organization's internal

d. Necessary strengthening of the organizational structure that supports the implementation of whistleblowing.

\section{REFERENCE}

[1] Abdul Haris Semendawai., et al. 2011. Understand The Whistleblower, Jakarta: Witness and Victim Protection Agency.

[2] The National Committee on Governance Policy (2008). Wrong Reporting System Guideline (Whistleblowing System - WBS).

[3] Alexander Dyck; Adair Morse; Luigi Zingales. 2010. Who Blows the Whistle on Corporate Fraud. The Journal of Finance, Vol. LXV, No.6, December 2010

[4] Association of Certified Fraud Examiners. 2016. ACFE Indonesia Chapter. Indonesia Survey Fraud. Web: http://www.acfe-indonesia.or.id/surveifraud-indonesia/.

[5] Alvin A. Arens., Randal J. Elder \& Mark S. Beasley. 2015. Auditing and Assurance Services Integrated Approach, Jakarta : Erlangga.

[6] John W. Creswell. (2014). Research Design, Qualitative, Quantitative, and Mixed Method Approaches.

[7] Gladys Lee; Neil Fargher.2012. Companies' Use of Whistle-Blowing to Detect Fraud: An Examination of Corporate Whistle-Blowing Policies. J Bus Ethics. 2013. 114:283-295.

[8] Agustin Fadjareni. The effect Of Independence, Proffesional Effects \& Auditor Experience On Audit Quality, International Journal Of Scientific \& Technology Research Volume 8 (02), 24-27.

[9] Ajzen, I. 1991. The Theory of Planned Behavior. Organizational Behavior and Human Decision Processes, Academic Press, 50, 179-211.

[10] Chin, W.W.1998. The Partial Least Squares Approach for Structural Equation Modelling. Dalam Marcoulides, G.A. (Ed.), Modern Method for Business research (hlm. 295-336). New Jersey : Lawrence Erlbaum Associates Publisher.

[11] Lawrence B. Sawyer., Mortimer A. Dittenhofer., James H.Scheiner (2006). Sawyer's Internal Auditing, Jakarta : Salemba Empat.

[12] Brief, A. P. and Motowidlo, S. J. 1986. Prosocial Organisational Behaviors, The Academy of Management Review, 11, $4: 710-725$.

[13] Hari Setiawan. The Effect Of Internal Controlling System, Government Accounting Standard and The Accomplishment of Audit Findings on The Quality of Financial 
Statement, International Journal of Science and Research (USR) 8 (5), 123-129.

[14] Prof. Dr. Sugiyono. 2016. Mixed Methods Research.

[15] Aaron B. Wilson; Casey McNellis; Claire Kamm Latham. 2018. Audit firm tenure, auditor familiarity, and trust: Effect on auditee whistleblowing reporting intentions. International J Audit. 2018; 1-18. wileyonlinelibrary.com/journal/ijau.

[16] Sugiyono. 2014. Educational Research Methods Quantitative, Qualitative and R\&D Approaches.

[17] Transparency International. 2017. Corruption Perceptions Index (CPI). Web: http://www.transparency.org/cpi.

[18] Association of Certified Fraud Examiners. 2016. ACFE Indonesia Chapter. Indonesia Survey Fraud. Web : http://www.acfe-indonesia.or.id/survei-fraud-indonesia

[19] Imam Ghozali. 2014. Structural Equation Modeling, Alternative Methods With Partial Least Square (PLS). 